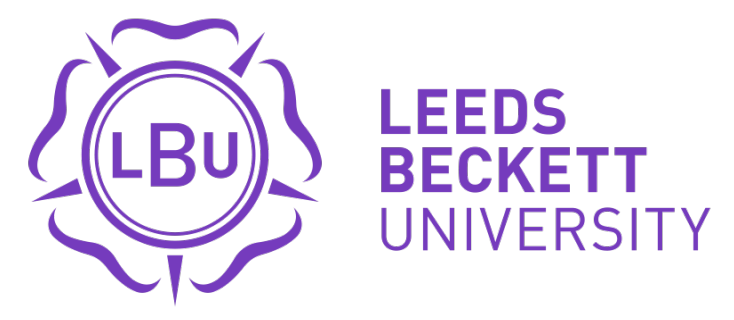

Citation:

Muleya, F and Zulu, S and Nanchengwa, P (2019) Investigating the role of the Public Private Partnership Act on private sector participation in PPP projects : A case of Zambia. The International Journal of Construction Management. ISSN 1562-3599 DOI: https://doi.org/10.1080/15623599.2019.1703088

Link to Leeds Beckett Repository record:

https://eprints.leedsbeckett.ac.uk/id/eprint/6423/

Document Version:

Article (Accepted Version)

Creative Commons: Attribution-Noncommercial-No Derivative Works 4.0

The aim of the Leeds Beckett Repository is to provide open access to our research, as required by funder policies and permitted by publishers and copyright law.

The Leeds Beckett repository holds a wide range of publications, each of which has been checked for copyright and the relevant embargo period has been applied by the Research Services team.

We operate on a standard take-down policy. If you are the author or publisher of an output and you would like it removed from the repository, please contact us and we will investigate on a case-by-case basis.

Each thesis in the repository has been cleared where necessary by the author for third party copyright. If you would like a thesis to be removed from the repository or believe there is an issue with copyright, please contact us on openaccess@leedsbeckett.ac.uk and we will investigate on a case-by-case basis. 


\title{
Investigating the role of the Public Private Partnership Act on private sector participation in PPP projects: A case of Zambia
}

\author{
${ }^{1}$ Franco Muleya, ${ }^{2}$ Sambo Zulu, ${ }^{3}$ Petra Chambwe Nanchengwa
}

\author{
${ }^{1}$ School of the Built Environment, The Copperbelt University, Kitwe, Zambia, \\ (Corresponding author: muleyaf@yahoo.co.uk) \\ ${ }^{2}$ School of the Built Environment \& Engineering, Leeds Beckett University, Leeds, England, \\ ${ }^{3}$ Graduate School, The Copperbelt University, Kitwe, Zambia
}

\begin{abstract}
The aim of this research was to investigate the role of this PPP Act on the private sector's decision to participate in PPP projects in Zambia. A mixed method design was adopted for this research due to limited information and stakeholders on the ground. 43 industry practioners representing contractors, developers' financiers and government were identified motivating a mixed method approach in order to obtain more data given a generally lower sample available. 27 questionnaires were obtained. Findings revealed that the PPP Act had not played a significant role to influence private sector decision to participate in PPP projects. The findings from this research unlocks part of the reason why there is little participation by private sector in PPP projects. The research identifies presents areas of focus in amending the Act in order to attract and influence private investment in current critical areas such as energy, higher education and housing among others. The study recommends immediate revision of PPP Act to remove identified barriers which among others include inadequate and unclear governing PPP framework, obstruction by bureaucracy, inappropriate risk sharing mechanisms and absence of protection to the private sector stakeholders.
\end{abstract}

Keywords: PPP Act role, private sector, public infrastructure, participation, Zambia

Keywords: PPP Act role, private sector, public infrastructure, participation, Zambia

\section{Introduction}

This paper discusses the influence of the Public Private Partnership (PPP) Act on private sector participation or investment in PPP projects in Zambia. The paper considers the background of the PPP concept and adoption in Zambia leading to the study on the PPP Act after which literature review is presented based on the region and beyond. Research methodology, findings, 
analysis and conclusion of the study are presented. Recommendation based on the outcomes from the study to the Zambian government are presented at the end of the conclusion section. According to a report by Devex (2008), the Government of the Republic of Zambia had set out a robust reform programme through the Private Sector Development (PSD) Programme; which was to be a platform on which Government would dialogue with the private sector on various issues with particular focus on reducing the cost of doing business in Zambia. Further, this platform was to effectively allow the private sector to be the main driver of the economic activities in the country. Through this initiative, and as part of the wider reform strategy, the Zambian government identified the Public Private Partnerships (PPPs) model as an alternative that would help address infrastructure development, rehabilitation and maintenance challenges of infrastructure. Further, it was to be an effective way to attract private sector investment in public infrastructure development programmes that were aimed at delivering good quality assets that linked economic activities in a cost-effective manner and quality delivery of essential public services to the citizens of the country Devex (2008). To this effect, in December 2008, Government approved a Policy Framework for the implementation of PPP's in Zambia which set out Government's objectives to facilitate the provision of infrastructure and effective delivery of social services using PPP platforms in order to attain economic growth through enhanced productivity, better competitiveness and wealth generation, ZDA (2014).

Following the Policy pronouncement by Government, the Zambian Parliament passed the PPP Act No. 14 of 2009 in August 2009, whose aim was to promote and facilitate the implementation of privately financed public infrastructure projects in order to provide better regulatory oversight on the projects, ZDA (2014). According to the PPP Act number 14 of 2009 the aim of the Act was to promote and facilitate the execution of privately financed infrastructure projects and effective delivery of social services by promoting transparency, 
fairness and long term sustainability and removing restrictions on participation by the private sector in the provision of social sector services and the development and operation of public infrastructure; establish a Public Private Partnership Unit and provide for its functions; establish the Public-Private Partnership Council and provide for its functions; provide for public-private partnerships for the construction and operation of new infrastructure and systems and the maintenance, rehabilitation, modernisation, and operation of existing infrastructure facilities and systems and the provision of social sector services; develop general principles of transparency, economy and fairness in the award of contracts by public authorities through the establishment of specific procedures for the award of projects and facilities and provision of social sector services and rules managing public-private inception, procurement, contracting and management of public-private partnerships; provide for the implementation of public-private partnership agreements between contracting authorities and concessionaires; and provide for matters connected with, or incidental to, the foregoing'. The aim of the Act and its objectives was to attract private sector participation in infrastructure development, however, the anticipated results were not achieved triggering many unanswered questions regarding the low participation levels especially from the local private sector stakeholders. The aim of this research was therefore to investigate the influence that the PPP Act had on the decision by the private sector to participate in PPP projects in Zambia.

\section{Background of PPP projects in Zambia}

According to the ZDA report of 2014, before the enactment of the PPP Act number 14 of 2009, the Zambian government had attempted to enter into four PPP projects of which three of them were not successful mainly due to the absence of the legal and regulatory arrangement. Other hindrances included lack of a PPP institutional arrangement at the time that the transactions were designed and executed. The transactions depended on the concession agreements signed 
with Government without a backup legal framework and other agreements which were porous.

Table 1 shows the major PPP project descriptions and status as indicated in the ZDA report of 2014

Table 1: PPP project before enactment of the PPP Act number 14 of 2009 (Source: ZDA, 2014)

\begin{tabular}{|l|l|l|l|}
\hline & $\begin{array}{l}\text { Year } \\
\text { signing }\end{array}$ & $\begin{array}{l}\text { PPP projects before the enactment of the } \\
\text { Act in 2009 }\end{array}$ & Status of the project \\
\hline 1 & 2000 & $\begin{array}{l}\text { 25 year concessioning of Mpulungu Harbour } \\
\text { Corporation to Agro Fuel Zambia in 2000. }\end{array}$ & $\begin{array}{l}\text { Concession cancelled by Government in } \\
\text { 2010 for failure to perform. }\end{array}$ \\
\hline 2 & $200 / 2001$ & $\begin{array}{l}\text { The 65 year build-own-transfer contract } \\
\text { between Lusaka City Council and China } \\
\text { Henan for the financing, construction, } \\
\text { operation and transfer of Luburma Market } \\
\text { around 2000/2001. }\end{array}$ & This concession is still running \\
\hline 3 & 2003 & $\begin{array}{l}\text { 20 year concessioning of Zambia Railways } \\
\text { assets to Railway Systems of Zambia in } \\
\text { 2003. }\end{array}$ & $\begin{array}{l}\text { Concession cancelled (in 2012) by } \\
\text { Government for breach of contract failure } \\
\text { to perform to Government's expectation }\end{array}$ \\
\hline 4 & 2009 & $\begin{array}{l}\text { 25 year Build-Operate- and Transfer (BOT) } \\
\text { contract Kasumbalesa One-Stop-Border Post } \\
\text { (operated as Zambian. Border Crossing } \\
\text { Company Limited) in July 2009. }\end{array}$ & $\begin{array}{l}\text { The contract was reversed by Government } \\
\text { (in 2012) }\end{array}$ \\
\hline
\end{tabular}

With the PPP based projects being generally unsuccessful before the enactment of the PPP Act of 2009, the Zambian government developed the PPP policy in order to ensure that a clear legal and regulatory framework as well as a functional institutional system was attained. This was designed to ensure that the expectations of the private investor, the government, and the public were equally and sustainably considered. However, it is visible that even after the enactment of the PPP Act in 2009, the Zambian government has only implemented few PPP projects as at 2018 and this could partly be attributed to lack of capacity as well as improper PPP institutional arrangement in the Ministry of Finance to implement such transactions, ZDA (2014). Table 2 shows the Zambian PPP projects (successful and unsuccessful) that were initiated after the enactment of the PPP Act in 2009. 
Table 2: Selected PPP projects after enactment of the PPP Act number 14 of 2009 (Source: ZDA 2014 and Muleya 2010)

\begin{tabular}{|c|c|c|c|}
\hline & $\begin{array}{l}\text { Year of } \\
\text { concession }\end{array}$ & $\begin{array}{l}\text { PPP projects before the enactment of the Act in } \\
2009\end{array}$ & Status of the project \\
\hline 1 & 2000 & Redevelopment of Long Acres Lodge & Agreement not yet consummated \\
\hline 2 & $200 / 2001$ & $\begin{array}{l}\text { Government Offices Complex (under Maintenance } \\
\text { Contract) }\end{array}$ & Completed (Under implementation) \\
\hline 3 & 2003 & UNZA Ultra-Modern business park (under BOT) & Completed (Under implementation) \\
\hline 4 & 2009 & $\begin{array}{l}\text { Construction of } 4000 \text { Housing Unit each in } \\
\text { Livingstone, Lusaka and Ndola (under BOOT) }\end{array}$ & Expression of Interest advertised \\
\hline 5 & 2009 & $\begin{array}{l}\text { Construction of a Railway Link - Njanji Commuter } \\
\text { Service Railway Line and North Western to } \\
\text { Namibia Rail line (Solwezi Katima Mulilo), } \\
\text { Chipata-Petauke- } \\
\text { Serenje Rail Line and the Livingstone-Katima } \\
\text { Mulilo Rail Line }\end{array}$ & Not yet commenced \\
\hline 6 & $\begin{array}{l}\text { First advert in } \\
2009\end{array}$ & $\begin{array}{l}\text { Conversion of the Zambian Main Trunk Roads into } \\
\text { Toll Roads and introduction of toll road gates } \\
\text { (under BOT) }\end{array}$ & $\begin{array}{l}\text { Commenced and ongoing } \\
\text { (First advert did not yield any } \\
\text { positive results) }\end{array}$ \\
\hline 7 & & $\begin{array}{l}\text { Development of Kafue Gorge Lower (KGL) Power } \\
\text { Station with a capacity of } 600 \text { to } 750 \mathrm{MW} \text { (under } \\
\text { BOT }\end{array}$ & Commenced and ongoing \\
\hline 8 & & $\begin{array}{l}\text { Development of Itezhi-Tezhi Hydro Power and } \\
\text { Transmission Line Project with a capacity of } \\
\text { 120MW (under } 25 \text { year Build-Own-Operate- } \\
\text { Transfer) }\end{array}$ & Completed in 2016 \\
\hline 8 & & $\begin{array}{l}\text { Development of Kabompo mini hydro power } \\
\text { station capacity of } 40 \mathrm{MW}\end{array}$ & Ongoing \\
\hline 8 & & $\begin{array}{l}\text { Development of Kalungwishi mini hydro with a } \\
\text { capacity of } 247 \mathrm{MW}\end{array}$ & Commenced \\
\hline 8 & & Development of Mombututu mini hydro & Under procurement \\
\hline
\end{tabular}

From the selected prominent PPP projects that are yet to commence and those that have already commenced, most of them are in the health, transport, agriculture and Energy. While some PPP projects have been completed and now operational, the number of successful projects still remains low despite the existence of a nationwide platform in the form of the PPP Act. According to a Zambian government report of the committee on economic affairs of 2016 energy and labour for the first session of the twelfth national assembly in October, 2016, Despite these efforts made in PPP platforms, the country had only been able to record four successful PPP 
projects namely, the Kasumbalesa One-Stop-Boarder post; Itezhi-Tezhi Hydro Power Corporation (ITPC); Luburma Market and the East Park Mall, while most of the earmarked projects under PPP had either failed to take off or the decisions were reversed. Several constraints had been identified as affecting the implementation of PPPs in Zambia included lack of clear guidelines and regulations, lack of cost reflective tariffs, lack of government guarantees and politics among others. Mukalula and Muya (2017) equally pointed out the successful; implementation of the East part Mall and Kasumbalesa one stop border post despite the later having being reversed and renegotiated in 2015 .

The data from table 2 shows that the energy sector has performed better than other sectors in terms of attracting private investment using the PPP platform following the commencement of Kafue Gorge lower power station. The downside of it is that it has seen increased pressure on the raising of electricity tariffs. In March 2019, the electricity company ZESCO applied for increase in tariffs by over 100\%. "The Energy Regulation Board (ERB) received an application from ZESCO Limited ("ZESCO" or "the Utility") to adjust the electricity tariffs (excluding mining and exports) by a weighted average rate of $113 \%$ as shown in the table 3" (www.erb.org.zm). This tariff increment application was in addition to the earlier increment of 50\%. This was happening at the time of carrying out the research.

Table 3: Proposed increased tariffs (Source- www.erb.or.zm)

\begin{tabular}{|c|l|c|}
\hline No & Customer Category & Proposed average increment \\
\hline 1 & Residential & $106 \%$ \\
\hline 2 & Large Power & $73 \%$ \\
\hline 3 & Small Power & $75 \%$ \\
\hline 4 & Distributor & New proposal \\
\hline 5 & Commercial & $170 \%$ \\
\hline 6 & Services & $143 \%$ \\
\hline & Total Weighted Average & $\mathbf{1 1 3 \%}$ \\
\hline
\end{tabular}


Further Ngandwe et al (2017) states that opportunities exist for PPP partnerships in areas of forestry but these opportunities are yet to be exploited. Ngandwe et al (2017) further states that Policies and legal frameworks have been developed and updated to promote PPPs in the country, particularly in infrastructure development, health and energy sectors. However, the forestry industry has not been listed among priority sectors for PPP development due to inadequate information about the subsector. The study concluded that the PPP potential areas include forest conservation, afforestation, value addition, bioenergy production. Formation of a private timber development agency is a major precondition to the development PPPs for SMEs in Zambia. Kemerink et al (2019) notes that a number of arguments have been forwarded to explain the difficulties faced in establishing functioning publicprivate partnerships (PPP) in the water services sector. Hall and Lobina (2005) argue that high transaction costs undermined the successfulness of PPP projects. These transaction costs include the legal, consulting and financial costs of establishing a PPP, managing the risks involved in the PPP and the establishment of regulatory agencies responsible for regulating the private operator.

Ngoma et al (2014), observed that Zambia, like many other countries, has embraced public-private partnerships (PPPs) as a project delivery method. The country faces budgetary constraints, which has caused the maintenance and provision of new infrastructures to be a challenge, however, benefits, constraints and risks regarding construction projects in Zambia were identified. Appropriate improvements to the regulatory framework were recommended for the PPP procurement approach to be successfully utilised and implemented in Zambia.

As seen from the short list of projects in tables 1 and 2, the private sector is yet to fully embrace opportunities under the PPP Act despite the existence of the PPP Act and a legal framework in place. Despite the low number of PPP projects so far, there is no known study that has considered the influence of the PPP Act and its contents on private sector decision in Zambia to participate in PPP projects in the midst of many opportunities in various sectors of the economy including at local authority level, a study that this paper focussed on. Table 4 shows 
the a list and summary of similar studies done on the PPP projects in Zambia with none focussing on PPP Act data analysis from industry practioners private inclusive. Many of the studies (for example, Ngoma, Mundiya and Kaliba, 2014; Mweemba, 2015 and Mukalula and Mundiya, 2019) indicate that the legislative environment is a major weakness in the lack of investment by the private sector.

Table 4: List and summary of similar PPP work done before in Zambia

\begin{tabular}{|c|c|c|c|}
\hline & Authors & Title & Focus of study \\
\hline 1 & Zulu and Muleya (2009) & $\begin{array}{l}\text { Delivering Infrastructure } \text { Development } \\
\text { using PPP/PFI: A Challenge for Zambia }\end{array}$ & $\begin{array}{l}\text { - Challenges surrounding implementation of public } \\
\text { projects using PPP mode. Paper recommended } \\
\text { improved policy and installation of independent } \\
\text { PPP watchdog }\end{array}$ \\
\hline 2 & Muleya (2010) & $\begin{array}{l}\text { Analysis of the new public private } \\
\text { partnerships act (PPP) number } 14 \text { of } 2009 \\
\text { and its new its proposed infrastructure } \\
\text { projects in Zambia. }\end{array}$ & $\begin{array}{l}\text { - Discussed challenges surrounding the PPP Act } \\
\text { and its implementation from a literature review } \\
\text { and expert analysis point of view. No field data } \\
\text { was collected }\end{array}$ \\
\hline 3 & Muleya (2011) & $\begin{array}{l}\text { Procurement of public infrastructure } \\
\text { through public-private partnerships in } \\
\text { Zambia }\end{array}$ & $\begin{array}{l}\text { - Discussed challenges surrounding proposed } \\
\text { projects driven by the then new PPP Act }\end{array}$ \\
\hline 4 & $\begin{array}{l}\text { Ngoma, Mundia and Kaliba } \\
\text { (2014) }\end{array}$ & $\begin{array}{l}\text { Benefits, Constraints and Risks in } \\
\text { Infrastructure Development via Public- } \\
\text { Private Partnerships in Zambia }\end{array}$ & $\begin{array}{l}\text { - Concluded that the PPP Act must revised to } \\
\text { include appropriate legislation but study never } \\
\text { investigated the Act to identify the bottlenecks } \\
\text { limiting preventing private sector interest and } \\
\text { participation }\end{array}$ \\
\hline 5 & Mweemba (2015) & $\begin{array}{l}\text { Risks associated with infrastructure project } \\
\text { finance in developing countries - the case } \\
\text { of Zambia }\end{array}$ & $\begin{array}{l}\text { - Regulations and guidelines missing in order to } \\
\text { provide in-depth guidance to both public and } \\
\text { private parties } \\
\text { - Transparent, predictable, flexible, responsive, } \\
\text { and equitable procurement systems for PPPs must } \\
\text { be put in place }\end{array}$ \\
\hline 6 & Abdelghaffar, et al (2016) & $\begin{array}{l}\text { Leveraging Chinese FDI For Diversified } \\
\text { Growth In Zambia }\end{array}$ & $\begin{array}{l}\text { - Parliament in } 1999 \text { passed the PPP Act No. 14, } \\
\text { providing the basic legal framework for PPPs, } \\
\text { which mobilize private sector financing to } \\
\text { support public infrastructure development. }\end{array}$ \\
\hline 7 & $\begin{array}{l}\text { Mukalula and Mundia } \\
\text { (2017) }\end{array}$ & $\begin{array}{l}\text { Evaluating Financial Risks in Zambia's } \\
\text { Public Private Partnership Projects: The } \\
\text { Case of the UNZA East Park Mall and } \\
\text { Kasumbalesa Border Post }\end{array}$ & $\begin{array}{l}\text { - Focused on financial risk analysis on the two PPP } \\
\text { projects }\end{array}$ \\
\hline 8 & $\begin{array}{l}\text { Zambia Institute for Policy } \\
\text { Analysis and Research } \\
\text { (ZIPAR) report (2017) }\end{array}$ & $\begin{array}{l}\text { Implementation of the Public Private } \\
\text { Partnership in Zambia }\end{array}$ & $\begin{array}{l}\text { - The current investment framework is not clear on } \\
\text { how sectors can incorporate PPPs. } \\
\text { - Government needs to strengthen the institutional } \\
\text { framework and have clear defined responsibilities } \\
\text { which are transparent. }\end{array}$ \\
\hline 9 & Stritzke (2018) & $\begin{array}{l}\text { 'Clean energy for all': The implementation } \\
\text { of Scaling Solar in Zambia }\end{array}$ & $\begin{array}{l}\text { - The study reviews critical success factors (CSFs) } \\
\text { for the implementation of the Scaling Solar } \\
\text { Programme in Zambia. } \\
\text { - the study indicates how a PPP framework, with a } \\
\text { redefined role of a horizontally integrated, } \\
\text { independent PPP Unit, can support this approach }\end{array}$ \\
\hline 10 & Lyambai (2018) & $\begin{array}{l}\text { Accelerating energy access through Public- } \\
\text { Private Partnership Investment in Zambia }\end{array}$ & $\begin{array}{l}\text { - The situation in Zambia shows low economic } \\
\text { productivity with high demographic growth, } \\
\text { which requires massive private sector } \\
\text { participation in order to provide sustainable } \\
\text { energy access to all people. } \\
\text { - Other approaches promoting private sector } \\
\text { investment in the energy sector are needed. At the } \\
\text { same time, Zambia needs to adjust financial }\end{array}$ \\
\hline
\end{tabular}




\begin{tabular}{|c|l|l|l|}
\hline & & & $\begin{array}{l}\text { markets and regulatory environments which can } \\
\text { support international and domestic public support } \\
\text { in order to catalyse private investment flows }\end{array}$ \\
\hline 11 & $\begin{array}{l}\text { Mukalula and Mundia } \\
(2019)\end{array}$ & $\begin{array}{l}\text { Risk Evaluation and Monitoring } \\
\text { Challenges of Public Private Partnership } \\
\text { Projects in Zambia: A Recipe for } \\
\text { Development Readiness, }\end{array}$ & $\begin{array}{l}\text { The introduction of the PPP law in Zambia has } \\
\text { not seen an improvement in the approval of } \\
\text { schemes particularly with respects to } \\
\text { quantification of risks embedded in proposals } \\
\text { submitted for development }\end{array}$ \\
\hline
\end{tabular}

\section{PPP definitions and context of research}

According to Xiong et al (2018) A public-private partnership (PPP) is an innovative procurement approach in which public and private actors co-operate to develop infrastructure and deliver public services, sharing risks, costs and benefits. According to (OECD, 2008) a public-private partnership is an agreement between the government and private partner or partners to which the private partners deliver the service in a way that the service delivery objectives of the government are aligned with the profit objectives of the private partners and where the accuracy of the alignment depends on a sufficient transfer of risk to the private partners. According to Hemming (2006), public-private partnerships (PPPs) refer to arrangements where the private sector supplies infrastructure assets and services that originally have been provided by the government. Hemming (2006) further states that in addition to private implementation and financing of public investment, PPPs have two other key characteristics: emphasis on service provision as well as investment, by the private sector; and identified risk is transferred from the government to the private sector. PPPs are involved in a wide range of social and economic infrastructure projects, but they are primarily used to build and operate hospitals, prisons, schools, selected roads, bridges and tunnels, rail networks, air traffic control systems, and sanitation and water plants. (Ibid). The viability of PPP projects depend on the separate evaluation of each project based on the region and legislation of each country or institution. Two PPP projects in separate countries or places may not be directly compared due to the unique nature of each project.

The ZDA report of 2014 defines PPPs as a public-private partnership that refers to joint cooperation between the public sector (government and/or its agencies) and the private sector (profit driven individuals or corporate entities) to share the benefits and risks in implementing specific projects The ZDA report of 2014 further states that it is a partnership between public institutions and the private sector for the construction, management and/or provision of an infrastructure or public service that can 
be considered to be a PPP. PPP's rely on the expectation that the private sector is better suited to provide an infrastructure or public service through:

- Higher operating efficiency

- Better service quality/reliability

- Cost-efficient use of public money on other public services

- Better value for money

- Transfer of selected risks to the private sector

- Transparency

According to Leigland (2018) the conventional view of PPPs is that, when compared with typical public projects, they should provide better service at lower costs. The private partner needs to make a profit, but the return should be reasonable. Projects that do not meet these expectations can be subject to public criticism from government, the news media, user groups, civil society, etc. Cost savings can be achieved through increase in efficiency and reduction in staffing and employment conditions (Skelcher, 2005). Cost savings are also the result of improved management through removal of excessive bureaucracy, increase in flexibility, and efficient implementation. Partnerships provides a great opportunity for government to access specialised expertise and state of the art technology from the private sector in order to serve the public interest (Seader, 2002). Scholars generally agree that partnerships can efficiently distribute particular risk to the partner best suited to manage that risk, and therefore the overall risk costs can be minimised (Allen 1999; Seader 2002; Skelcher 2005).

PPP systems involve the purchase of a stream of services, defined in a detailed service agreement under specified terms and conditions, Walker and Smith (1995). This is done through a concession contract which involves a host government granting a license or concession to a private consortium which consolidates a single purpose entity known as a Special Purpose Vehicle (SPV) using contracts secondary to the concession, to finance, design, 
deliver and manage infrastructure project for a period of time referred to as the concession period, Walker and Smith (1995). Cui et al (2018) states that Public-Private Partnerships (PPP's) are widely used to deliver a series of infrastructure projects in the world. The PPP approach increases the economic value of infrastructure outputs and facilitates to the overall development of infrastructure, such as the establishment of transportation infrastructure, sports facilities, water conservancy facilities, and waste-to-energy plants.

\section{Regulatory frameworks of PPP programmes}

The regulatory framework relevant to private involvement in infrastructure constitute a series of laws, regulations, notices, circulars, and implementing guidelines according to Bellier and Zhou (2003). Regulatory framework signifies government institutions, such as ministries, departments, units and divisions, and government laws, regulations, policies and guidelines, Appuhami and Rerela (2011). A study by Kumaraswamy and Zhang (2001) emphasised the importance of having a well-founded regulatory framework to control the PPP process as it can be evaluated as the main indicator of success/failure of PPP policy. Regulation is required to assure that a balance of public and private interests is reached through partnering arrangements Pongsiri (2002). However, the nature of the regulatory framework varies from country to country, particularly between developed and developing countries (Rafael et al, 1997). Various studies have put forth that the establishment of regulatory framework in developing countries has been inadequate. For example, Pongsiri (2002) and Pessoa (2006) pointed out that even though developing countries have initiated PPP programs, most have not yet designed the appropriate regulatory framework.

Similarly, Appuhami and Rerela (2011) suggests that the weak regulatory framework has major challenge for the implementation of PPPs thereby failing to attract private sector participation. 
However, Xiong et al (2018) adds that regulation establishes a clear institutional framework for developing, procuring and implementing PPPs but do not necessarily take priority sector laws. This is true for the prevailing platform for Zambia and other developing countries as seen in the literature cited, however, in developed countries like Canada, Australia and the United Kingdom who have successfully adopted PPP practice, there are independent units which facilitate and promote PPPs. There are rules, guidelines and regulations that clearly define the relationship between the public and private sectors, Appuhami and Rerela (2011).

Ateloye et. al., (2016) states that the Nigerian government put in place some reforms for private sector participation in the development of the education sector. These reforms are Public Private Partnership Initiative (PPPI) such as , Adopt-a-School, Community Accountability and Transparency Initiative (CATI), Private Development Initiative (PDI) and Higher Education Collaboration (HEC) to mention but a few. According to Thomas and Thomas (2013), these reforms have not made significant difference in the sector, however there is an acknowledgement of a knowledge gap in understanding the reasons behind private sector's reluctance to partner with government.

Kavishe et. al., (2016) states that despite the absence of a PPP legal framework, Tanzania had adopted PPP's in a few sectors including housing. For a number of years, the country has been facing a severe shortage of adequate housing. The government advised its housing agencies to adopt PPP strategies in order to deliver more adequate houses, yet the deficiency remains high and progress is slow. This resulted in first a PPP Policy, then a PPP Act in 2010 and eventually the approval of regulations in 2011. A PPP Coordination Unit was established by the 2010 PPP Act within the Tanzania Investment Centre (TIC) to organise and monitor the Tanzanian PPP projects and PPP Financing Unit within the Ministry of Finance. This was done with 
responsibility to assess and examine all PPP proposals in their financial aspects. Despite the establishment of these units none of the PPP projects passed through them for assessment and approval. Bengesi and Mrema (2016) observed that Private sector participation in PPP, particularly in projects related to transportation infrastructure, still remains low despite the government's efforts in creating a conducive operative environment. This questions the quality or adequacy of the enabling policy, legal and institutional mechanisms; harmony in the understanding of the PPP concept between the two parties.

Ismail and Harris (2014) states that, the PPP initiative was officially announced in Malaysia under the Ninth Malaysia Plan of 2006 that it was introduced by the Malaysian Government as an optional procurement method, which emphasised significant participation of private sector providers in providing public services. PPP implementation in Malaysia has proven to provide numerous benefits to the Government and the public in general. Through PPP projects, Malaysia has experienced many successful projects that can benefit the public; however, there are also barriers that hinder the successful implementation of PPP projects through the possibility of project default, higher cost of projects to the Government and where value for money is not realised, Cheung (2009). Okwaro et. al. (2017), indicates that the government of Kenya has worked towards attracting private sectors in PPP's through the use of legal and regulatory framework. This resulted in the Public Private Partnership Act, No. 15 of 2013, published in the Kenya Gazette Supplement No. 27 of 25th January 2013. Consequently, the PPP Act came into effect on 8th February 2013. However, there hasn't been much action in the implementation of PPP projects.

According to the research, the following are the factors that affect the implementation: (a) Lack of policy direction on the adoption of PPP procurement and (b) Centralisation of the PPP 
implementation unit in the national treasurer .Lack of PPP experience and knowledge was of much concern to potential private investors and the government. Okwaro et al (2013) further asserts that lack of understanding and experience by public officials involved in PPPs require better training and capacity building in relevant areas of the PPP procurement process, such as commercial, legal, technical and sector knowledge. Majority of the investors have no confidence in the country's procurement process which may have hindered their interest in the adoption of PPP procurement

A study by (ZEPARU 2016) on six African countries revealed bureaucracy and interference by government were significant in the PPP project approval process which is a critical issue for local and international investors. The six countries comprised Uganda, Tanzania, Lesotho, Malawi, Kenya and Zimbabwe. Government institutions such as the Cabinet or the Office of the President in all these countries are also involved in the approval process of PPP projects in the sectors which include transport, water, energy, properties, housing, medical (hospital) and education. This piece of literature shows that the bureaucratic challenges in the implementation of PPP projects is not unique to Zambia except that none of these countries has demonstrated the influence that the PPP framework and policies have influenced private sector investment on these countries, a study that this research focusses on but in Zambia.

AmCham, (2014) highlights that despite the enactment of the PPP Act, the Bulgarian experience with PPP is not extensive. Henceforth, relying on the international experience, a successful long-term PPP program in Bulgaria would require three general driving factors: (a) Political and public support, (b) Effective and transparent procurement process and (c) Administrative capacities to initiate, prepare, negotiate and procure PPP projects. Despite government plans, a number of projects have been delayed, or cancelled. The necessary activities for project planning as required by the PPP Act have not been performed. As a result, 
the continuity and the predictability in respect to planned or future PPP projects have decreased negatively affecting the interest of the private investors. In Bulgaria a more decentralised approach was adopted, and the results up to now, do not appear particularly positive: no projects initiated under the PPP Act; delays in preparation of major concessions and certain regional projects; there has not been many PPP success stories in the last couple of years. On the other hand, the PPP Bulgarian Act has been identified with some deficiencies such as limitations of the scope of the PPP Act; constrains regarding the potential PPP private partners; complex procurement procedures and unnecessary involvement of the central government in the activities of the municipalities

From the literature reviewed, it can be deduced that the main reasons for low participation in PPP projects by the private sector, include but not limited to: untrusted governance system; corruption; inability of the government to be transparent enough in the process of project award; Inadequate PPP skills, experience and knowledge (Administrative capacities to initiate, prepare, negotiate and procure PPP protects); insufficient government guidelines and procedures; Lengthy delays in negotiation process; Lack of policy direction on the adoption of PPP procurement; Inadequate instruments and capacity to meet long-term equity and debt financing and PPP unit being centralised in the national treasurer or being under the wing of the government. Limited private sector involvement at decision making levels and sub structures was identified as one of the reasons for failure to attract the private sector in participating in PPP projects. It is evident that despite putting in place legal framework such as Acts of parliament and policies to facilitate procurement and implementation of PPP projects, there has been limited attraction to the private sector especially in developing countries due to inadequacies of the frameworks and other governance and experience related matters.

\section{Research methodology}


The aim of this research was to investigate the influence that the PPP Act had on the decision by the private sector to participate in PPP projects in Zambia. With the PPP concept being new to Zambia there were few participants at the time of conducting the research in 2018. This prompted the research to identify a maximum of 43 industry practioners representing contractors, developers' financiers and government potential units regarding the planning and execution of PPP projects. Of the 43 participants, 15 were potential developers/contractors with capacity to undertake PPP projects, 23 were from private financial institutions mainly banks operating in the country, 4 were major local authorities and the only PPP unit which sits in the Ministry of Finance. The respondents were at managerial and director level in order to get credible information that was both policy and operational in nature. The number of players in the areas of study and practice is still low hence the small sample size. Considering this small sample size, a mixed method approach was adopted in order to collect all the required and available data for this research. Questionnaires were designed based on the analysis of the Act in relation to the previous literature outlined below and summarised in table 9. One of the main reasons for using questionnaires based on the Likert scale was to rank the factors in order to determine the most important or significant factors responsible for keeping developers and financiers from investing in PPP projects. Qualitative data was obtained from published documents such as the PPP Act, the ZDA reports, government reports, Muleya (2010), Zulu and Muleya (2009) among others.

This method of selecting factors for analysis from existing literature is supported by (OseiKyei et al, 2017; Osei-Kyei, R., \& Chan, APC, 2017) whose research method involved carrying out thorough review of earlier literature in order to develop a comprehensive set of criteria for measuring PPP project success. Further Osei-Kyei et al (2018) conducted a thorough review of both institutional and academic literatures to identify the relevant causes and resolution 
mechanisms of conflicts in PPPs. From the review, 16 factors believed to be the causes of conflicts in PPPs and four conflict resolution mechanisms were identified. A total response twenty seven (27) participants was recorded representing a response rate of $63 \%$. While the sample size is small, it is the maximum number of respondents at director and managerial levels that was identified in the country and the results are therefore reliable. Different studies in the built environment have used smaller samples but with reliable results attained. For example, Sarkar and Mangrola (2016) had a sample size of 35. Other studies who based their findings on small sample sizes include Owusu-Manu, et al (2017), Pheng et al (2016), Pheng et al. (2002) who had 30, 32 and 23 participants respectively. Reasons for choosing smaller samples included among others small population of respondents, limited number of experts in areas of specialisation and difficulties in accessing the target population.

The PPP Act for Zambia was analysed in detail with support in reference to similar studies as already mentioned. Purposive sampling method was adopted in order to obtain data that was credible from reliable respondents that had interest and/or understanding of the PPP platform in Zambia considering the small population involved. The data was run in SPSS version 24 software in order to obtain the rankings of the factors which was critical factor in establishing the significance and importance of the barriers to PPP participation by the private sector.

\section{Results, analysis and discussion}

A total of twenty-seven (27) completed questionnaires out of 43 were received and subsequently analysed for discussion representing a response rate of $63 \%$ of the sample. The results were analysed based on the methods explained in the research methodology section and discussed according to each section in the questionnaire and respective questions asked accordingly. The Likert scale of 1 to 5 was used in order to rank the importance and significance of the parameters under investigation by obtaining the Relative Importance index. Statistical 
Package for Social Sciences (SPSS 24) was used to collate and analyse the data leading production of tables and rankings of parameters followed by the interpretation.

The formula for Relative Importance Index is as follows:

$$
\begin{gathered}
\text { RII }=\frac{\sum \mathrm{W}}{A N} \\
\text { Or } \\
\text { RII }=\text { Sum of weights }(\mathrm{W} 1+\mathrm{W} 2+\mathrm{W} 3+\ldots \ldots+\mathrm{Wn}) / \mathrm{A} \times \mathrm{N}
\end{gathered}
$$

where $w$ is the weighting given to each factor by the respondent, ranging from 1 to 5 in which " 1 " is the least important and " 5 " the most important; A is the highest weight, in this study A $=5 ; \mathrm{N}$ the total number of samples.

Table 5 shows the details for the respondents from private institutions. Table 6 shows respondents from selected government institutions including the PPP unit which is responsible for operational activities of the PPP Act in Zambia. There are no sub committees or units operating in different ministries. All PPP related projects are handled by the PPP unit under the Ministry of Finance which makes it difficult to champion the PPP agenda because different ministries have different types and approaches to project implementation depending on the

\begin{tabular}{|c|c|c|c|}
\hline Institution & Sampling Technique & Sample Size & Response Rate \\
\hline $\begin{array}{l}\text { Contractors and/or } \\
\text { Developers }\end{array}$ & Purposive Sampling & 15 & 15 \\
\hline Financiers & Purposive Sampling & 23 & 10 \\
\hline Total & & 38 & 25 \\
\hline
\end{tabular}
variations in the in nature and operation of each ministry.

Table 5: Respondents from selected Private Institutions 


\begin{tabular}{|c|c|c|c|}
\hline Institution & Sampling Technique & Sample Size & Response Rate \\
\hline PPP Unit & Purposive Sampling & 1 & 1 \\
\hline City Council & Purposive Sampling & 4 & 1 \\
\hline Total & & $\mathbf{5}$ & $\mathbf{2}$ \\
\hline
\end{tabular}

\section{Awareness of PPP and PPP Act}

This section compares the levels of knowledge of PPP and the PPP Act in Zambia. The aim was to establish the difference in knowledges levels between PPP and the PPP Act in Zambia. While PPP awareness is general the PPP Act is more specific to each country

Table 7: Mean for level of knowledge on PPP and PPP Act from the Private sector and public sector perspectives

\begin{tabular}{|l|l|r|r|r|r|}
\hline Item & Level of Knowledge & \multicolumn{2}{|c|}{ Private Sector } & \multicolumn{2}{|}{ Public sector } \\
\hline & & $\begin{array}{c}\text { Developers } \\
(\mathrm{N}=15)\end{array}$ & $\begin{array}{r}\text { Financiers } \\
(\mathrm{N}=10)\end{array}$ & $\begin{array}{r}\text { Local Gov } \\
(\mathrm{N}=1)\end{array}$ & $\begin{array}{r}\text { Central Gov } \\
(\mathrm{N}=1)\end{array}$ \\
\hline & PPP & 3.73 & 3.20 & 5.00 & 5.00 \\
\hline b) & PPP Act & 2.67 & 2.70 & 5.00 & 5.00 \\
\hline
\end{tabular}

Table 7 shows the mean for the levels of knowledge in the private sector with PPP knowledge being higher at 3.73 for developers and 3.20 for financiers such as banks and other financial institutions. The level of knowledge on the PPP Act was lower at means of 2.67 and 2.70 for developers and financiers respectively. .This result signifies that the private sector was more knowledgeable on the PPP programme than on the PPP Act. This further shows that the PPP Act has not caught the attention of private stakeholders signifying that the presence of the Act alone is not enough to attract private stakeholders. It is however interesting to note that in the same table 7, the public sector at central and local government levels showed the same mean of 5.00 for PPP and the PPP Act level of knowledge. This result signifies that the public sector is more knowledgeable on both the PPP programme as well as the PPP Act. The sufficient 
knowledge from the public sector is as a result of sector being the generators of the PPP Act which has however not been widely marketed and brought to the attention of private sector stakeholder partners.

\section{PPP Act barriers to Private Sector participation}

This section discusses the factors that have hindered private sector participation in PPP projects. This is in line with the lower knowledge level of the PPP Act displayed by the private sector. Various barriers were cited as reasons for low interest in the Act and its application to PPP projects in Zambia. Table 8 shows the mean, Relative Importance Index and ranking of the barriers categorised under developers, financiers and public sector:

Table 8: PPP Act Barriers to private sector participation in PPP projects from Private sector and public sector perspectives

\begin{tabular}{|c|l|c|c|c|c|c|c|c|c|c|}
\hline Item & \multicolumn{1}{|c|}{ Influencing Factors } & \multicolumn{2}{|c|}{ Developers (N=15) } & \multicolumn{3}{c|}{ Financiers (N=10) } & \multicolumn{3}{|c|}{ Public sector (N=2) } \\
\hline & & Mean & RII & Rank & Mean & RII & Rank & Mean & RII & Rank \\
\hline a) & Deficiency in PPP Framework & 3.87 & 0.773 & 1 st & 4.40 & 0.88 & 1 st & 4.00 & 0.80 & $2 \mathrm{nd}$ \\
\hline b) & Transparency and Accountability & 3.27 & 0.653 & $2 \mathrm{nd}$ & 2.50 & 0.50 & 6 th & 4.50 & 0.90 & $1 \mathrm{st}$ \\
\hline c) & Obstructed by Bureaucracy & 2.93 & 0.587 & $3 \mathrm{rd}$ & 3.60 & 0.72 & $2 \mathrm{nd}$ & 1.50 & 0.30 & $3 \mathrm{rd}$ \\
\hline d) & Capacity and Specialised Skills & 2.87 & 0.573 & 4 th & 2.80 & 0.56 & 4 th & 1.50 & 0.30 & $3 \mathrm{rd}$ \\
\hline e) & $\begin{array}{l}\text { Relevant Skills to Negotiate with } \\
\text { the Private Sector }\end{array}$ & 2.87 & 0.573 & 4 th & 2.60 & 0.52 & 5 th & 1.50 & 0.30 & $3 \mathrm{rd}$ \\
\hline f) & View of Bureaucracy & 2.87 & 0.573 & 4 th & 2.90 & 0.58 & 3 rd & 4.00 & 0.80 & $2 \mathrm{nd}$ \\
\hline g) & Influenced by Risk Sharing & 2.80 & 0.560 & 5 th & 2.40 & 0.48 & 7 th & 1.00 & 0.20 & 4 th \\
\hline h) & Assurance or Protection to the & 2.67 & 0.533 & 6 th & 2.80 & 0.56 & 4 th & 4.50 & 0.90 & 1 st \\
\hline i) & Private Sector & & & & & & & & \\
\hline
\end{tabular}

Table 8, shows respondents from the private contractors, developers and public sector. Deficiency in PPP framework, Low transparency and accountability, obstruction by bureaucracy, capacity and specialised skills and protection of private sector were ranked as the top barriers to private sector participation in PPP projects. Deficiency in PPP framework was 
ranked first by the private sector while the public sector ranked transparency and accountability and protection of the private sector as the first barrier to successful implementation of PPP projects in Zambia. The ranking pattern arises from the structure of the Act which is characterised by bureaucracy and unbalanced representation of units resulting in reduced confidence of the Act and the PPP agenda. The Act demonstrates that government seeks to totally control the PPP identification and procurement process without giving enough platform for the financiers and developers to be part of the decision making process as seen in table 8 . It is evident from the results that the private sector has little confidence that government would fulfil its great and attractive objective of the PPP Act hence the low interest and less knowledge of the details of the Act. The structure of the Act does not give confidence to both the public and private sectors thereby failing to attract large volumes of private investors. Governance perspective, equity and inclusiveness are lacking in the PPP Act and its implementation.

These results verify the outcome of Muleya (2010) that the PPP Act number 14 of 2009 in Zambia does not attract private sector involvement because of limited participation provided for by Act. Muleya (2010) further recorded and predicted that the limited inclusion of the private sector in key levels of the PPP framework in Zambia would not attract private investment in public infrastructure and services. The study further pointed out the PPP council was dominated by ministers and presidential appointees while the technical committee consisted of permanent secretaries with representation from other government related institutions with few from the private sector. The study suggested amendments to the Act to consider increasing private sector participation being the ones bringing in the financial and technical resources. It was also proposed that transparency and accountability be championed in order to gain the confidence of the private sector. This study however was based on the analysis of the PPP Act alone in relation to the limited response to PPP projects at the time. The research results from this current study on the other hand was based on data collected from 
various key stakeholders under the PPP umbrella in Zambia. Table 9 shows the bodies of the

PPP Act and their functions with accompanying risk analysis based on reference to literature

review, Muleya (2010) and author in-depth analysis of the PPP structure and its capacity to

attract private investment

Table 9: Summary of mandates and composition of PPP bodies (Source: extracted from the PPP Act number 14 of 2009 and Muleya 2010)

\begin{tabular}{|c|c|c|c|c|}
\hline & $\begin{array}{l}\text { PPP BODY IN } \\
\text { THE ACT }\end{array}$ & $\begin{array}{l}\text { COMPOSITION OF } \\
\text { BODY }\end{array}$ & FUNCTIONS OF THE BODY & RISKS IDENTIFIED \\
\hline 1 & PPP UNIT & $\begin{array}{l}\text { - Not disclosed except for } \\
\text { the Director. } \\
\text { - No structure or } \\
\text { establishment made } \\
\text { available to the public. }\end{array}$ & $\begin{array}{l}\text { - } \text { Promote private sector } \\
\text { participation in PPP projects } \\
\text { - Identify projects for the Act } \\
\text { - Develop and technical and best } \\
\text { practice for PPP } \\
\text { - Assess submitted proposed } \\
\text { projects } \\
\text { - Train project officers } \\
\text { - Promote PPP awareness } \\
\text { - Approve consultancy assignments } \\
\text { - Examine project proposals } \\
\text { - Project auditing } \\
\text { - Advise government on PPP } \\
\text { procedures }\end{array}$ & $\begin{array}{l}\text { - Capacity of the PPP unit to } \\
\text { undertake all these is not } \\
\text { known. } \\
\text { - The unit has no experience to } \\
\text { undertake these unless they } \\
\text { rely on consultants which } \\
\text { erodes investor confidence } \\
\text { - The internal PPP unit must } \\
\text { have capacity to handle PPP } \\
\text { projects with minimal } \\
\text { external support. }\end{array}$ \\
\hline 2 & $\begin{array}{l}\text { PPP } \\
\text { COUNCIL }\end{array}$ & $\begin{array}{l}\text { - Minister of finance as } \\
\text { chair } \\
\text { - Four ministers } \\
\text { appointed by the } \\
\text { republican President } \\
\text { - Four other people } \\
\text { appointed by the } \\
\text { republican President. } \\
\text { - Finance ministry } \\
\text { permanent Secretary }\end{array}$ & $\begin{array}{l}\text { - Formulate PPP policies for the } \\
\text { - Act } \\
\text { - Approve projects or reject } \\
\text { projects. } \\
\text { - Ensure transparency and fairness } \\
\text { of PPP project. } \\
\text { - Give directions to contracting } \\
\text { authorities. } \\
\text { - Request technical assistance }\end{array}$ & $\begin{array}{l}\text { - Composition may not } \\
\text { comprise technocrats to } \\
\text { make decisions. } \\
\text { - Consultation from external } \\
\text { experts is not enough. } \\
\text { - } 100 \% \text { members appointed } \\
\text { by the President creating } \\
\text { unbalanced representation } \\
\text { by excluding the private } \\
\text { sector. It's not attractivefor } \\
\text { private sector stakeholders. } \\
\text { - Leaving out private sector } \\
\text { members is against the aim } \\
\text { of the Act. }\end{array}$ \\
\hline 3 & $\begin{array}{l}\text { PPP } \\
\text { TECHNICA } \\
\text { L } \\
\text { COMMITTE } \\
\text { E }\end{array}$ & $\begin{array}{l}\text { - Secretary to the } \\
\text { treasury as chair } \\
\text { - Four ministry } \\
\text { permanent secretaries } \\
\text { - Attorney general } \\
\text { representative. } \\
\text { - One representative } \\
\text { from } \\
\text { - Engineering } \\
\text { institution } \\
\text { - National Council for } \\
\text { construction } \\
\text { - Environmental } \\
\text { council. } \\
\text { - Procurement } \\
\text { authority and }\end{array}$ & $\begin{array}{l}\text { - Advice the PPP council and unit } \\
\text { on technical matters. } \\
\text { - Recommend award of } \\
\text { agreements. } \\
\text { - Evaluate and select projects for } \\
\text { award to council } \\
\text { - Recommend approval of Projects } \\
\text { - Perform assignments form the } \\
\text { council }\end{array}$ & $\begin{array}{l}\text { - Composition may not be } \\
\text { technocrats to make sound } \\
\text { decisions. Consultation } \\
\text { from experts is not enough. } \\
\text { - Key private sector } \\
\text { institutions left out such as, } \\
\text { architects, estimators, } \\
\text { planners, land surveyors, } \\
\text { etc. Consulting bodies may } \\
\text { not be enough. } \\
\text { - Not enough training and } \\
\text { exposure to competently } \\
\text { deal with the mandate. }\end{array}$ \\
\hline
\end{tabular}




\begin{tabular}{|l|l|l|l|}
\hline & $\begin{array}{l}\text { Economic } \\
\text { association. } \\
\bullet \text { Two members } \\
\text { appointed by the } \\
\text { Minister }\end{array}$ & & \\
\hline
\end{tabular}

Comparing Muleya (2010), Zulu and Muleya (2009) and table 2, the current PPP Act has struggled to attract significant private investment along with other listed challenges and inadequacies, the same problem that is being experienced in other countries as cited in the literature review. Table 8 clearly shows that the Act and its contents can hardly encourage investors to enter into PPP projects with government. Much of the officers presiding over the procurement and implementation of PPPs are political appointees whose loyalty is to the appointing authority leaving out private sector stakeholders. The private sector is not represented in the key decision making units exposing to all types of risks. The unbalanced and inexperienced composition of the PPP bodies as provided for by the Act presents serious risk to the private sector triggering caution in entrusting resources with an inexperienced team of politicians. This further weakens the Act's inability to influence the private sector's decision to invest in PPP projects. The results from this study confirm the study by Tshombe and Molokwane (2016) who concluded that every government should have legislation in place as well as a regulatory framework on PPPs to facilitate local and foreign investors to implement new projects. The absence of a legal and regulatory framework on PPPs hinders close collaboration between the public and private sector in certain countries in Sub-Saharan Africa.

\section{Practical implications of research findings}

With deficiency in PPP framework, low transparency and accountability, obstruction by bureaucracy, lack of capacity/specialised skills and lack of protection of private sector identified as PPP Act barriers to private sector participation in Zambia, investment levels in PPP public projects across the country will remain low as seen in tables 1 and 2 . This further implies that Zambian will not benefit from private investment in public infrastructure such as 
schools, universities, energy and housing due to an Act that is standing a bottle neck to private sector investment in public works. The Zambian central and local governments will benefit from these research findings by focussing on specific areas of improvement in the PPP Act based on the evidence contained in this study.

The PPP Act if not revised will continue to hinder the flow of private investment into public sector infrastructure. Zambia needs significant private sector investment in the provision of public infrastructure and services because government is struggling to meet the requirements technically and financially. As an example, according to the Zambia's higher education $\begin{array}{llllll}\text { Authority updated website accessed on } 17 & \text { November } 2019\end{array}$ (https://www.hea.org.zm/index.php/public-heis), Zambia has 10 provinces with 7 public universities present only in 4 provinces. 6 provinces have no public universities creating a serious deficit in higher education service. Table 10 provides a summary of the statistics whose gap can be closed by private sector investment should the listed bottlenecks in the PPP Act be removed and create incentives for private sector investment in public universities.

Table 10: Zambia state provinces and existing public universities (Source: adapted from the higher education authority website, https://www.hea.org.zm/index.php/public-heis)

\begin{tabular}{|c|l|c|}
\hline & PROVINCE & $\begin{array}{c}\text { NUMBER OF } \\
\text { PUBLIC } \\
\text { UNIVERSITIES }\end{array}$ \\
\hline 1 & Central Province & $\mathbf{2}$ \\
\hline 2 & Copperbelt Province & $\mathbf{2}$ \\
\hline 3 & Eastern Province & $\mathbf{0}$ \\
\hline 4 & Luapula Province & $\mathbf{0}$ \\
\hline 5 & Lusaka Province & $\mathbf{2}$ \\
\hline 6 & Muchinga Province & $\mathbf{1}$ \\
\hline 7 & Northern Province & $\mathbf{0}$ \\
\hline 8 & North-Western Province & $\mathbf{0}$ \\
\hline 9 & Southern Province & $\mathbf{0}$ \\
\hline 10 & Western Province & $\mathbf{0}$ \\
\hline
\end{tabular}


According to the Zambia Electricity company (ZESCO) website (http://www.zesco.co.zm/ourBusiness/generation), Zambia has a deficit of hydro power generation amounting to 1,181 Mega Watts as shown in table 11 due to low water levels at hydro generation power stations attributed to low rainfall patterns which have been ultimately linked climate change. This has resulted in load management periods of 12 hours per day. Further, figure 1 shows that $82.79 \%$ of power generation was hydro based (ERB 2018 sector report).

Table 11: ZESCO hydro power generation capacity against available capacity (Source: http://www.zesco.co.zm/ourBusiness/generation)

\begin{tabular}{|l|l|l|}
\hline POWER STATION & \multicolumn{1}{|c|}{$\begin{array}{c}\text { GENERATION } \\
\text { CAPACITY (MW) }\end{array}$} & $\begin{array}{l}\text { AVAILABLE } \\
\text { CAPACITY (MW) }\end{array}$ \\
\hline Kafue Gorge & 900 & 630 \\
\hline Kariba North Bank & 1080 & 275 \\
\hline Victoria Falls & 108 & 108 \\
\hline Itezhi Tezhi & 120 & 120 \\
\hline Lunzua & 14.8 & 5.9 \\
\hline Lusiwasi & 12 & 8.6 \\
\hline Chishimba & 6.2 & 3.5 \\
\hline Musonda & 5 & 4 \\
\hline Shiwang'andu & 1 & 1 \\
\hline Total & $\mathbf{2 , 3 3 7}$ & $\mathbf{1 1 5 6}$ \\
\hline
\end{tabular}




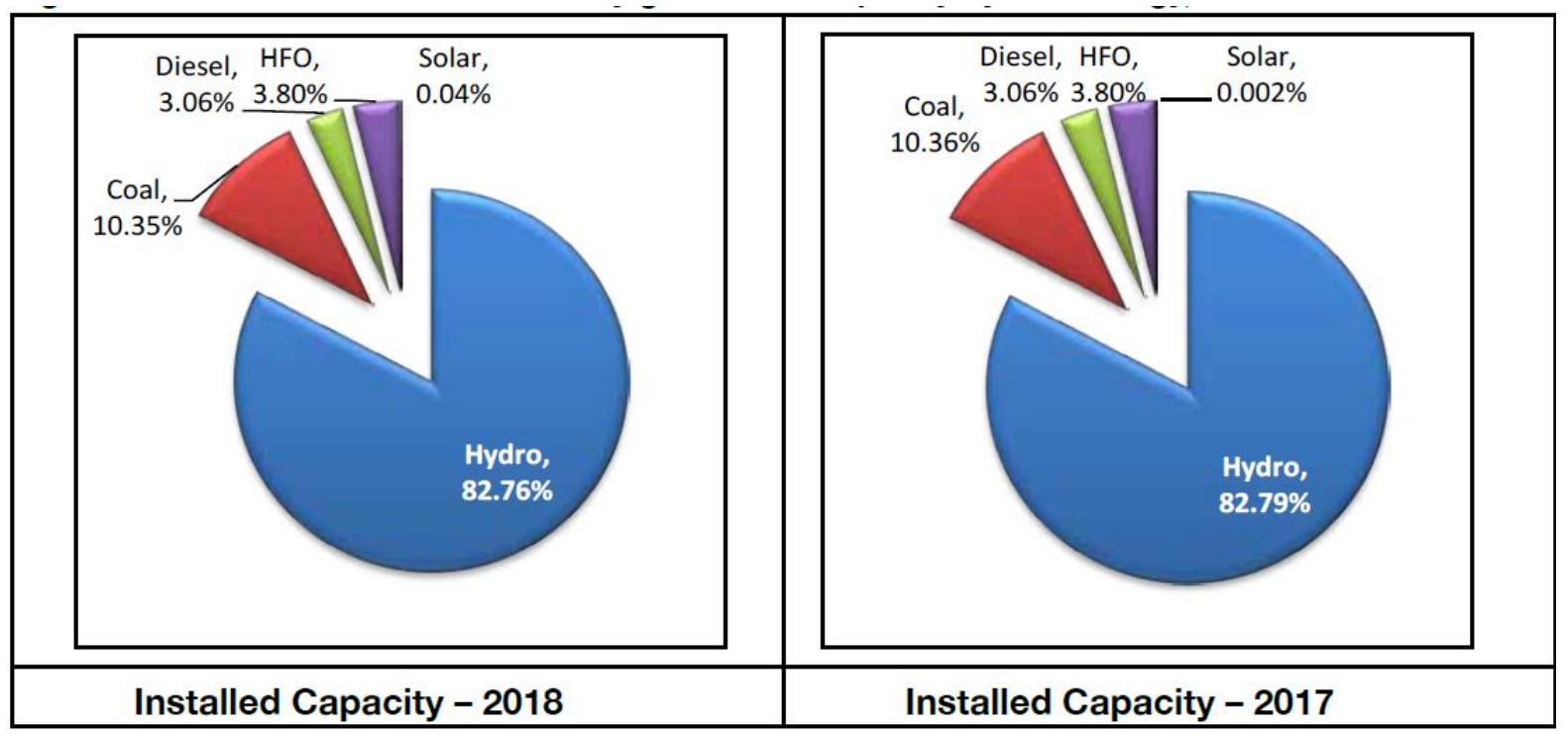

Figure 1: National installed electricity generation capacity by technology, 2018 and 2017 (Source: ERB sector report, 2018)

This is evidence of the opportunity that exists in cleaner energy generation such as solar which the private sector can invest however, this is likely not to happen as long as the PPP Act is not amended to remove the barriers identified in this paper. The ZESCO website shows public private partnerships have taken off at Kafue Gorge Lower hydro, Itezhi tezhi hydro and Kariba North bank hydro power plant extension but not in cleaner and sustainable such as solar. According to the ERB 2018 sector report, solar investment and contribution only constituted $0.04 \%$ as seen in figure 1 . The removal of barriers in the PPP Act is likely to attract private sector investment into the cleaner and more sustainable sources of energy such as solar which are currently partly hindered by the prohibitive PPP Act.

Another sector that requires private participation is housing. Zambia is struggling with a deficit of housing units standing at 1.5 million at as 2018 according to the Ministry of Housing and infrastructure website https://www.mhid.gov.zm/government-to-construct-5000-houses-forcivil-servants-in-zambia/. The figure is projected to double if nothing is done by 2030. This prompted the Zambian government to allocate ZMW 3.46 billion in the 2020 budget on housing 
and community amenities which includes ZMW 2.62 billion towards water supply and sanitation (KPMG 2020 budget highlights for Zambia, 2019). This housing sector is one area that the private sector can close up the deficit but the identified bottleneck necks in the PPP Act must first be removed in order to attract private investment via PPP in the housing sector like other sectors mentioned. Zambia will continue struggle with public infrastructure deficit if legal framework surrounding the PPP Act is not corrected as presented in this paper's research findings.

\section{Conclusion}

The study concludes that there are few projects in Zambia that have been executed under the PPP Act of 2009 from the time it was enacted in 2009. The study established that the low number of PPP projects was not as result of low PPP knowledge for both the public sector. This was the same for private sector developers and financiers. This is because knowledge levels of PPP were high for these stakeholders. Further the study concluded that the low the number of PPP projects was instead attributed to barriers that the PPP Act of 2009 has not addressed. The identified barriers to private sector participation in PPP projects include deficiency in PPP framework, lack of transparency and accountability; obstructed by bureaucracy and absence of protection to the private sector developers and financiers through inappropriate risk sharing mechanisms. The PPP Act has to a large extent failed to attract expected private sector investment in the PPP public projects. The study recommends revision of the Act to remove the identified barriers failure to which will render the current PPP Act ineffective and inappropriate thereby keeping private investment away from PPP projects in Zambia. Finally the results from this study verifies the outcome from previous studies that used different methodologies that PPP Act of 2009 for Zambia was inclined to protect the interest of the public sector and not the private stakeholders thereby keeping private investment in PPP 
projects low. The study recommends immediate review of the PPP Act to involve private sector participation through removal of identified barriers. Failure to remove the barriers will result negligible private sector investment in critical public infrastructure and services such energy, housing and education that are experiencing serious deficit in terms of infrastructure and associated services. Further the composition of the PPP governing structures must include the private sector stakeholders in order to provide confidence to private sector investment failure to which the PPP Act will only remain a document that will not attract significant private sector investment for public infrastructure and services

\section{References}

Allen JR. 1999. Public-Private Partnerships: A review of Literature and Practice. Saskatchewan Institute of Public Policy. Public Policy Paper No.4.

AmCham (American Chamber of Commerce in Bulgaria). 2014. Introduction PPP in Bulgaria. [Internet], accessed at http://amcham.bg/wp-content/uploads/2014/06/AmCham-PPPWG_PPP-Position_ENG_FINAL.pdf

Appuhami RP, Perera H. 2011. Coercive Policy Diffusion in a Developing Country: The Case of Public-Private Partnerships in Sri-Lanka. Journal of Contemporary Asia. 41(3): 431-451.

Ateloye ABG, Oyegoke A. 2016. Private Sector Participation in Nigeria Higher Education Infrastructure Development. In: P W Chan and C J Neilson (Eds.) Proceedings of the 32nd Annual ARCOM Conference, 5-7 September 2016, Manchester, UK, Association of Researchers in Construction Management, Vol 2, 969-977.

Bellier M, Zhou YM. 2003. Private Participation in Infrastructure in China: Issues and Recommendations for the Road, Water, and Power Sectors. World Bank, International Finance Corporation. World Bank working paper; no. 2.

Bengesi K, Mrema T. 2016. Public Private Partnership in Tanzania's Transportation Infrastructure: the Way PPP is Understood, Challenges and the way Forward, Economic and Social foundation policy brief, Technical report. Number 2/2016 Available from: https://www.researchgate.net/publication/310442649_Public_Private_Partnership_in_Tanzan ia's_Transportation_Infrastructure the Way_PPP_is_Understood_Challenges_and the way Forward [accessed Jun 012018 ]

Caiyun Cui, Liu Yong, Hope Alex, Wang Jianping. 2018. Review of studies on the publicprivate partnerships (PPP) for infrastructure projects, International Journal of Project Management, https://doi.org/10.1016/j.ijproman.2018.03.004 
Cheung E. 2009. Developing a best practice framework for implementing Public Private Partnerships (PPP) in Hong Kong. Unpublished doctoral dissertation, Queensland University of Technology: Queensland.

Devex .2008. Public- Private Partnerships (PPP) Type Projects in Zambia, [Internet], viewed on 1st August 2016, https://www.devex.com/funding/tenders/25328/25328

Energy Regulation Board of Zambia sector report 2018, http://www.erb.org.zm/reports/esr2018.pdf

Hemming R. 2006. Public-Private Partnerships Government Guarantees and Fiscal Risk, International Monetary Fund, Fiscal affairs department, Washington DC

http://www.erb.org.zm/downloads/notices/2019-04-03_PCP.pdf, date accessed 9/4/2019

http://www.mof.gov.zm/jdownloads/Public-

Private\%20Partnership/ppp_information_brochure.pdf $\quad$ https://doi.org/10.11111/14678500.12343

https://www.mhid.gov.zm/government-to-construct-5000-houses-for-civil-servants-in-zambia

https://www.hea.org.zm/index.php/public-heis

http://www.zesco.co.zm/ourBusiness/generation, accessed 17 November 2019

Ismail S, Harris FA. 2014. Challenges in implementing public private partnership (PPP) in Malaysia International Conference on Accounting Studies 2014, ICAS 2014, 18-19 August 2014, Kuala Lumpur, Malaysia

Kavishe N, An M .2016. Challenges for Implementing Public Private Partnership in Housing Projects in Dar es Salaam City, Tanzania. In: P W Chan and C J Neilson (Eds.) Proceedings of the 32nd Annual ARCOM Conference, 5-7 September 2016, Manchester, UK, Association of Researchers in Construction Management, Vol 2, 931-940.

Kemerink J, Mbuvi D, Schwartz K. 2019. "Governance shifts in the water services sector: a case study of the Zambia water services sector." Water Services Management and Governance, IWA Publishing, England

KPMG 2020 budget highlights for 2019. https://home.kpmg/content/dam/kpmg/us/pdf/2019/10/tnf-zambia-2020-budget-oct1-2019.pdf Accessed 17 November 2019

Kumaraswamy M, Zhang X. 2001. Governmental Role in BOT-Led Infrastructure Development. International Journal of Project Management. 19(4):195-205.

Leigland J. 2018. Public-Private Partnerships in Developing Countries: The Emerging Evidence-based Critique, The World Bank Research Observer, Vol. 33, No.1 February2018

Lyambai M. 2018. Accelerating energy access through Public-Private Partnership Investment in Zambia, Research-2-Practice Forum on Renewable Energy, Water and Climate Security in Africa 16 - 18.04.2018, Tlemcen, Algeria 
Mukalula P, Mundia M. 2017. Evaluating Financial Risks in Zambia's Public Private Partnership Projects: The Case of the UNZA East Park Mall and Kasumbalesa Border Post, 4th International Conference on Development and Investment in Infrastructure - Strategies for Africa, Livingstone, Zambia, 30 August - 1 September, 2017, pp 286-295, ISBN: 978-0-620$74121-7$

MukalulaP, Mundia M. 2017. Risk Evaluation and Monitoring Challenges of Public Private Partnership Projects in Zambia: A Recipe for Development Readiness, 5th International Conference on Development and Investment in Infrastructure - Strategies for Africa, Livingstone, Zambia, 24 - 26 July, 2019 Livingstone, Zambia, pp 118-126, ISBN: ISBN: 978-0-620-81856-8

Muleya F. 2010. Analysis of the New Public Private Partnerships Act (PPP) Number 14 of 2009 and its New Proposed Infrastructure Projects in Zambia, National Council of Zambia

Muleya F. 2011. Procurement of public infrastructure through public-private partnerships in Zambia, The Echo, Engineering Institution of Zambia, Issue number 15 2nd quarter (April June 2011

Mweemba B. 2015. Risks associated with infrastructure project finance in developing countries - the case of Zambia, unpublished masters thesis, Nelson Mandela Metropolitan University (NMMU), Eastern Cape, South Africa

Nadia A, Karli B, Chuin S, Bu MC, Brandon L, Roger L, Kabira N, Diana P, Aya S, Chex Y. 2016. Leveraging Chinese FDI for Diversified Growth in Zambia, The Woodrow Wilson School Graduate Policy Workshop, https://wws.princeton.edu/sites/default/files/content/Zambia\%20Final\%20Final\%20Report_2 7Apr2016.pdf, accessed 19 November 2019

Ng'andwe P; Chungu D; Ratnasingam J; Ramananantoandro T; Donfack P, Mwitwa J .2017. Forestry industry development in Zambia: an opportunity for public private partnership for small and medium enterprises, International Forestry Review, Volume 19, Number 4, December 2017, pp. 467-477(11)

Ngoma S, Mundia M, Kaliba C. 2014. Benefits, Constraints and Risks in Infrastructure Development via Public-Private Partnerships in Zambia. Journal of Construction in Developing Countries, 19(1), p.15.

OECD .2008: Public-private partnerships: in pursuit of risk sharing and value for money, GOV/PGC/SBO (2008)1/REV1, Public Governance and Territorial Development Directorate Public Governance Committee, OECD, Paris.

Okwaro KO, Chepkwony J, Boit R .2017. Factors affecting adoption of public-privatepartnership in county government of Uasin Gishu, Kenya. International Academic Journal of Procurement and Supply Chain Management, 2(3), 33-56

Pongsiri N .2002. Regulation and public private partnerships, The International Journal of Public Sector Management, Vol. 15 No. 6, pp. 487-95. 
Osei-Kyei R, Chan APC. 2017. Comparative Analysis of the Success Criteria for PublicPrivate Partnership Projects in Ghana and Hong Kong. Project Management Journal, Vol. 48, No. 4, 00-00

Osei-Kyei R., Chan APC, Javed AA, Ameyaw E.E. 2017. Critical success criteria for publicprivate partnership projects: International experts' opinion. International Journal of Strategic Property Management, 21(1), 87-100

Osei-Kyeia R, Chan APC, Chanb, Yuc Yao YC, Chenc C, Dansohd A. 2018. Root causes of conflict and conflict resolution mechanisms in public-private partnerships: Comparative study between Ghana and China, https://doi.org/10.1016/j.cities.2018.10.001

Owusu-Manu D, Addy MN, Agyekum K, Aidoo C. 2017. Exploring the critical success factors of Ghanaian built environment consulting firms. International Journal of Construction Project Management, 9(2), 137-152.

Pheng L, Gracia T. 2002. Relationship marketing: A survey of QS firms in Singapore. Construction Management \& Economics. 20. 707-721. 10.1080/0144619022000014051

Pheng LS, Shang, G, Foong, WK .2016. Enhancing construction productivity through organizational learning in the Singapore construction industry. International Journal of Construction Project Management, 8(1), 71.

PPP Act for Zambia, https://ppp.worldbank.org/public-privatepartnership/sites/ppp.worldbank.org/files/ppp_testdumb/documents/zambia_ppp_act_2009.pd f, Accessed 13/06/2018

Rafael L, Lopez-De-Silanes F, Shleifer A, Vishny R .1997. Legal Determinants of External Finance. Journal of Finance. 52(3): 1131-1150.

Sarkar D, Mangrola M. .2016. Development of lean integrated project delivery model for highway projects. International Journal of Construction Project Management, 8(1), 25.

Seader DL .2002. The United States' Experience with Outsourcing, Privatization and PublicPrivate Partnerships. The National Council for Public-Private Partnerships: www.ncppp.org

Skelcher C .2005. Public-Private Partnerships and Hybridity, The Oxford Handbook of Public Management, Oxford University Press.

Susann S. 2018. Clean energy for all': The implementation of Scaling Solar in Zambia, https://ora.ox.ac.uk/objects/uuid:643fd752-bbf7-4a74-865a-

6c7acc48d254/download_file?file_format=pdf\&safe_filename $=$ Clean $\% 2 B E n e r g y \% 2 B Z a m b i$ a\%2BPPP\%2Brevised\%2B09\%2B03.pdf\&type of work=Journal+article, November 2019

Thomas OA, Thomas-olufuwa AS. 2013. Public Private Partnership and Management of Higher Education in Nigeria, Journal of Educational Review, Vol.6, No.1, PP.109-117 
Tshombe LM, Molokwane T. 2016. An analysis of public private partnership in emerging economies Risk Governance \& Control: Financial Markets \& Institutions / Volume 6, Issue 4, Fall 2016

Walker C, Smith AJ .1995. Privatized infrastructure: the BOT approach. London: Thomas Telford.

Xiong W, Chen B, Wang H and Zhu D. 2019. Governing public-private partnerships: A synthetic review of case study literature, Australian journal of public administration

Zambia Development Agency (ZDA) .2014. Public-Private-Partnerships in Infrastructure Development in Zambia, [Internet], accessed at $<$ www.zda.org.zm/?q=download/file/fid/60 $>$

Zambian government report of the committee on economic affairs, energy and labour for the first session of the twelfth national assembly appointed on 5th October, 2016, http://www.parliament.gov.zm/sites/default/files/documents/committee_reports/ADOPTED\% 20REPORT\%200N\%20ECONOMIC\%20AFFAIRS.pdf, date accessed 12/09/2019

Zambia Institute for Policy Analysis and Research (ZIPAR) report .2017. Submitted to the Committee on Economic Affairs, Energy and Labour of the National Assembly of Zambia, http://www.zipar.org.zm/research/our-publications/parliamentary-submissions/31-publicprivate-partnerships-in-zambia-1/file, accessed 19 November 2019

Zimbabwe Economic Policy Analysis and Research Unit (ZEPARU) 2016, draft report submitted to the Macroeconomic and Financial Management Institute for Eastern and Southern Africa (MEFMI)

Zulu S, Muleya F. 2009. Delivering Infrastructure Development Using PPP/PFI: A Challenge for Zambia International Conference paper presented at the $4^{\text {th }}$ Association of Schools of Construction of Southern Africa (ASOCSA) at the Zambezi sun in Livingstone. 